\title{
The Changes in the Daily Activities Cycle of Women Informal Workers during the COVID-19 Pandemic: Vulnerability and Resilience
}

\author{
Desintha Dwi Asriani, ${ }^{1}$ Dati \\ Fatimah, ${ }^{2}$ Mida Mardhiyyah, ${ }^{3}$ \\ Aminatun Zubaedah ${ }^{4}$ \\ ${ }^{1}$ Department of Sociology, Faculty of \\ Social and Political Sciences, \\ Universitas Gadjah Mada - Indonesia; \\ 23,4SRI Institute, Yogyakarta- \\ Indonesia
}

Corresponding Author: Desintha Dwi Asriani, email: desintha@ugm.ac.id, Jl. Sosio-Justisia No. 2 Bulaksumur Yogyakarta 55281, Indonesia

\begin{abstract}
This article is based on research discussing the daily activities cycle of women that work in the informal sector during the Pandemic of COVID-19 in Yogyakarta. The research method is qualitative, followed by gender perspective, to affirm the narrative based on women's experiences and gender analysis. On one side, economic recession due to the Pandemic of COVID-19 has increased the vulnerability of women in the informal sector because their income depends on daily economic activity. On the other side, the implementation of social distancing has increased women's workload at home. However, culturally, women's works in private sectors such as care works and mothering tend to be normalized. Economic activity is associated with men's jobs as breadwinners, and it is limited on public space. Therefore, women seem not productive economically even though they have endless works (at home). This article does not only explore one single aspect of women's double burdens. But it is also to discuss how women's identical activity with care works has been disconnected from the economic cycle chain itself. Meanwhile, living in the time of pandemic COVID-19 shows that women's works become the vital pillar of resilience in handling crisis, whether in health and economy.
\end{abstract}

Keywords: women; COVID-19; informal sector; double burdens; care works

\begin{abstract}
Abstrak: Artikel ini merupakan hasil penelitian ini yang mengkaji tentang siklus aktivitas harian perempuan pekerja sektor informal di masa pandemi COVID-19 di Yogyakarta. Metode penelitian yang digunakan adalah kualitatif dengan menyertakan perspektif gender untuk mengafirmasi narasi berbasis pengalaman perempuan dan analisis gender. Di satu sisi, resesi ekonomi di masa pandemi telah meningkatkan kerentanan perempuan pekerja sektor informal karena pendapatan mereka bergantung pada aktivitas ekonomi harian. Di sisi lain, pemberlakuan pembatasan sosial justru meningkatkan beban kerja perempuan di rumah. Namun secara budaya, kerja perempuan di ranah privat seperti kerja perawatan dan pengasuhan cenderung dinormalisasi. Aktivitas ekonomi diasosiasikan dengan kegiatan laki-laki pencari nafkah dan dalam batasan ruang publik. Sehingga perempuan menjadi tampak tidak produktif secara ekonomi meskipun mereka memiliki pekerjaan (rumah) yang tidak ada habisnya. Artikel ini tidak hanya membahas satu aspek tentang beban ganda perempuan, namun juga untuk mendiskusikan bagaimana aktivitas perempuan
\end{abstract}




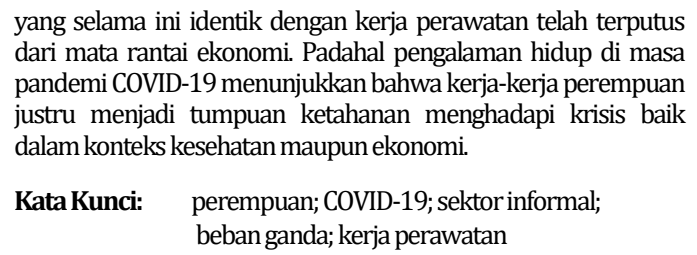

\section{A. Introduction}

"The personal is political" is an expression that is always relevant to discuss women's issues concerning other social issues. The term was popular among second-wave feminists in the 1960-1970s to question public and private dichotomy in a patriarchal society. This dichotomy creates a standardization of roles and spaces where women seem to be part of the private sphere that is personal, natural, and separate from public life. The regulation of power and political discourse is associated with men who are considered to have more capacity to move to the public (outside of house) and formulate important policies. Meanwhile, based on women's daily experiences living in a patriarchal private and public structure are two aspects that support, influence, and intervene. In other words, everything that is part of the personal sphere of women is closely related to how the public structure is to be organized for certain interests. ${ }^{1}$ Thus, discussing women's daily lives is important to understand how and to what extent the COVID-19 pandemic has been managed both culturally and policy.

Narratives about daily life also help explain the layers and varieties of problems within the women's group itself. As is known, there is nothing essential in defining women. ${ }^{2}$ The definition of woman is never single but a process of being closely related to the subject's experience in interacting with her social world, so it is no longer trapped in the twin concept of superordinate/subordinate. For example, women who have careers cannot necessarily be considered as empowered subjects than housewives or vice versa. This is the case with the dynamics of women workers in the informal sector. Data on women's participation in the informal sector on a national and

${ }^{1}$ Jane Freedman, Concepts in the Social Sciences Feminism (Buckingham: Open University Press, 2003).

2Lena Gunnarsson, “A Defence of the Category 'Women,"' Feminist Theory 12, no. 1 (2011): 23-37, https://doi.org/10.1177/1464700110390604. 
global scale continues to increase. ${ }^{3}$ Culturally, because of the limitations of social norms, many women are "forced" to have their daily lives as part-time workers or in the informal sector. Cultural problems also often create dilemmas for women in managing their routines as if there is a need to balance public and domestic roles. Thus, working in the informal sector is often seen as a tactic even though it sometimes seems fake because informal sector actors tend to control resources and limited social protection. However, it does not mean that it can be concluded that the existence of women in the informal sector has no meaning or does not have an essential contribution to themselves, their families and the wider community.

It can be said that women's work is presented at the same time marginalized to maintain the establishment of a patriarchal and capitalistic economic system. On the one hand, women are "laid off" and do unpaid domestic work as producers of surplus value for the capitalist system. On the other hand, some women can access paid work in the public sphere, but only as cheap laborers or working in sectors that are not far from private activities such as services and maintenance where the recognition is still low. However, on the other hand, the willingness of women to become laborers or workers in the informal sector is also driven by the limitations of traditional household relationships which are apparently not capable enough to solve the problem of poverty.

Gender perspective can be used to avoid generalization of disaster analysis, including during the COVID-19 pandemic. At least a gender perspective can help explain that the impact and vulnerability caused by each disaster is not the same for men and women. Women often receive a greater risk than men because of their economic, social, and cultural disadvantages. The specific situation of women is often ignored in policy formulation. It becomes increasingly difficult for women to access important resources such as food, safe houses, and reproductive health facilities during a disaster. ${ }^{4}$

\footnotetext{
33iro Pusat Statistik, "Perilaku Masyarakat di Masa Pandemi Covid-19," bps.go.id, 2020, https://www.bps.go.id/publication/2020/09/28/f376dc33cfcdeec4a514f09c/perilakumasyarakat-di-masa-pandemi-covid-19.html.

${ }^{4}$ Ahmad Ayesha, "Conceptualizing Disasters from a Gender Perspective," in Disasters: Core Concepts and Ethical Theories, ed. Dónal P. O"Mathúna, Vilius Dranseika, and Bert Gordijn (Switzerland: Springer International Publishing, 2018), 105-18.
} 
Likewise in the context of the COVID-19 pandemic, using a gender perspective is very important to reveal the different impacts experienced by men and women. This difference is undoubtedly prevalent, considering the system of norms and culture socialized for men and women has also been different. Gender construction also creates a dichotomy between men's and women's social roles and their daily standards of behavior. So the absence of impact analysis and disaster policies with a gender perspective during a pandemic can be considered as an ahistorical or baseless step. Many criticisms of this kind have been made, such as how lockdown policies in several countries are not accompanied by risk management related to the double burden of mothers, the vulnerability of women to become victims of domestic violence, and the limitations of women in meeting their reproductive health needs.

On the other hand, some survey data have mapped several differences in the impact of the COVID-19 pandemic on a gender basis. For example, UN Woman - Asia Pasific data ${ }^{5}$ shows that the factors that cause productivity loss between men and women are different. The congestion for women to continue to be productive (economically) is mainly caused by the inability to adapt to technology. Through BPS data, it is known that men experience more layoffs than women. ${ }^{6}$ It raises a question mark regarding whether female workers are likely to be retained because they are often conditioned as low-wage laborers. Besides, Komnas Perempuan (Indonesia National Commission of Women) found that policies or recommendations for social restrictions resulted in domestic violence increasing because it was difficult for women to escape and find a safe house. ${ }^{7}$

Gender politics in disaster analysis, including the COVID-19 pandemic is indeed quite clear, presenting evidence that vulnerability and risk are never universal. However, because the gender perspective departs from fighting all forms of discrimination, it is feared that this vulnerability mapping will only

${ }^{5}$ UN Woman - Asia Pasific, "Indonesia and COVID-19: Impact on the Private Sector," asiapacific.unwomen.org, 2020, https://asiapacific.unwomen.org/en/digital-library/publications/ 2020/08/indonesia-and-covid-19-impact-on-the-private-sector.

${ }^{6}$ Biro Pusat Statistik, "Perilaku Masyarakat di Masa Pandemi Covid-19."

${ }^{7}$ Komisi Nasional Anti Kekerasan terhadap Perempuan, "Pernyataan Sikap Komnas Perempuan: Urgensi Perspektif HAM dengan Perhatian Khusus pada Kerentanan Perempuan dalam Penanganan Pandemi Covid-19," komnasperempuan.go.id, 2020, https://komnasperempuan.go.id/ pernyataan-sikap-detail/pernyataan-sikap-komnas-perempuan-urgensi-perspektif-ham-denganperhatian-khusus-pada-kerentanan-perempuan-dalam-penanganan-pandemi-covid-19. 
sharpen women's subordinate positions. The deeper meanings of just "differences" were left out of the discussion. Therefore, tracing women's daily lives can be a strategic way where there is a wider space to accommodate women's authentic narratives, voices, and imaginations and in their capacity as an autonomous and free subject or what has come to be known as agency. However, the agency here is also understood in the sense of frontal resistance to oppressive situations or protests against the state because the handling of COVID-19 is deemed not on target. But the agency here refers to Mahmood Saba's concept of the capacity of action, which refuses to always position women only as objects of discourse. ${ }^{8}$ So, that amid assumptions about the risks experienced by women due to a patriarchal structure, it is also important to discuss women as subjects who can interpret cultural processes and their choice of action autonomously or known as active resistance. For example, in certain conditions, during the COVID-19 pandemic, some women volunteered to take the initiative to set up public kitchens and even sell food from home because their husbands were laid off. It can be read that women are being used again in difficult situations to reduce the burden on the state. This women's attitude is sometimes normalized as women's morale is associated with volunteerism or the assumption that every mother must be willing to sacrifice for her child and family. On the other hand, this attitude can be seen as a form of women's active resistance when various policies and even state institutions can no longer be used as a basis.

Thus, the point is that a daily political approach, especially concerning the impact of the COVID-19 pandemic, can explain how far the gender construction has created spaces and situations that are detrimental to women. But on the other hand, this approach is also useful in understanding how far women take advantage of their daily personal, domestic, and sometimes considered economic values as an effort to survive and even defend others amid a prolonged crisis

In general, this article departs from the argument that a pandemic will cause a health crisis and an economic recession where the impact is felt directly by the informal sector. In the context of women's daily lives, this article seeks to further discuss the complexity of women's experiences in the informal sector

\footnotetext{
${ }^{8}$ Saba Mahmood, "Feminist Theory, Embodiment, and the Docile Agent: Some Reflections on the Egyptian Islamic Revival," Cultural Anthropology 16, no. 2 (2001): 202-36, https://doi.org/ 10.1525/can.2001.16.2.202.
} 
during the COVID-19 pandemic and its implications for discussing the broader social structure. This social structure can be related to cultural and logical problems that underlie policies in both disaster and economic contexts.

This article is expected to be an alternative reference where the use of a gender-based approach in analyzing the impact of COVID-19, especially in Indonesia, has so far been very limited. Existing studies have been discussed a lot about the extent of the country's response to the impact of COVID-19. ${ }^{9}$ The rapid study conducted by Masudi and Winanti is also very important, which is related to the level of knowledge and governance design to increase community/society resilience in crises. ${ }^{10}$ There is also a more specific study on the link between the impact of COVID-19 and the issue of sexuality and reproductive rights developed by MacKinnon and Bremshey which emphasizes a critical analysis of how a pandemic that is not accompanied by a gender-based approach has exacerbated women's inequality and vulnerability. and other marginal groups. However, in the studies mentioned above, there is not much information regarding mapping the daily narratives of marginalized groups such as women and their implications for gender-based disaster studies and policies. $^{11}$

The method used in this research is qualitative equipped with a gender perspective. It refers to the feminist methodology ${ }^{12}$ that states that to be consistent with the change agenda and dismantle the status quo, methods that emphasize women's experiences and aspects of gender equality need to be put forward. This effort is very likely to be carried out through a qualitative approach, where the primary data source is based on the narrative exploration of the informants. Specifically, the informants who participated in this study were 40 male and female informal sector workers, but with a composition of

\footnotetext{
${ }^{9}$ Riyanti Djalante et al., "Review and Analysis of Current Responses to COVID-19 in Indonesia: Period of January to March 2020," Progress in Disaster Science 6 (2020): 100091, https://doi.org/10.1016/j.pdisas.2020.100091.

${ }^{10}$ Poppy S. Winanti and Wawan Mas'udi, Tata Kelola Penanganan COVID-19 Di Indonesia: Kajian Awal (Yogyakarta: Gajah Mada University Press, 2020).

${ }^{11}$ Jessica MacKinnon and Alexane Bremshey, "Perspectives from a Webinar: COVID-19 and Sexual and Reproductive Health and Rights," Sexual and Reproductive Health Matters 28, no. 1 (2020): 1763578, https://doi.org/10.1080/26410397.2020.1763578.

${ }^{12}$ Maria Mies, "Toward a Methodology for Feminist Research," in Theories of Women's Studies, ed. Gloria Bowles and Renate Klein (London: Routledge, 1983), 117-39; Aparna Rayaprol, "Feminist Research: Redefining Methodology in the Social Sciences," Contributions to Indian Sociology 50, no. 3 (2016): 368-88, https://doi.org/10.1177/0069966716657460.
} 
70:30. The number of women is higher because we believe that the articulation space for women has been limited. It is also related to the purpose of this study which seeks to go beyond an androcentric bias approach. However, that does not mean we claim the reproduction of knowledge has been carried out through "wrong" methods. The affirmation given to women's groups who have tended to be "invisible" so far is one of the strategies in gender studies to provide alternative discourses so that discourse and knowledge reproduction can run in balance.

The data collection techniques developed in this study are literature study, observation, and online interviews. Technically, the research in this study was conducted in the early days of the COVID-19 pandemic, where many still felt stuttering in responding to the pandemic disaster. Because state policies are still limited, there have been many independent lockdowns carried out by local communities. So that people's mobility is minimal, either because they are afraid or worried that they will not pass through the portals installed at each door of their residential area. Therefore, the determination of informants was carried out through purposive and snowball techniques starting from the researchers' closest environment. Regarding further data collection, interviews were also conducted online using telephone and WhatsApp calls.

Variations in informant characteristics include gender, type of work and educational background. In general, the informal sector is understood as a sector of work with low wages, uncertain income but with limited access to social protection. This definition allows for a fairly broad range of informal sector jobs. In this study, the informal sector workers who were successfully recruited generally have very diverse types of work. However, if categorized, it can be stated that many of them are active in the culinary, agriculture, microeconomics, services, and care sectors.

Meanwhile, women mostly dominate in the service and care works. It is also exciting information in gender analysis where there are categorizations in the informal sector that affect differences in risk, vulnerability, and potential resilience. However, so far, not much has been discussed in theoretical literature or policies that focus on disaster management. Another interesting thing is that the highest educational background is high school graduates. It can also be said that the informal sector is an alternative for those who are not competitive enough in the formal labor market, which is more accessible to highly educated groups. 


\section{B. The Impact of the COVID-19 Pandemic and Changes in Socio- Economic Structures}

Pandemics are becoming a landscape that influences how social and economic changes occur at an unprecedented pace. Even before the pandemic, the World Economic Forum, for example, predicted that the labor market landscape would change with massive artificial intelligence, automation, the internet of things, and cloud technology. ${ }^{13}$ No one imagined the speed at which changes would occur. The Pandemic is changing social interaction as part of physical distancing, has forced a much more rapid change with changes in interaction and economic and social modes changing from offline to online, massive automation and the internet of things. Changes due to physical distancing have also left many economic sectors shaken due to changing ways and priorities of life. For example, the transportation sector is severely affected because large-scale social restrictions much reduce physical mobility. Or, the tourism sector is affected. For example, in the SMERU study, six sectors were seriously affected by the pandemic in Indonesia. The six sectors are accommodation providers: food and beverage, trade, transportation, construction, other services, and the processing industry. ${ }^{14}$

However, change always has a non-singular narrative of impact. While some sectors were seriously affected by the pandemic as described above, several other sectors have increased. We can say, the information technology sector or the health sector, which is an important priority in the list of daily life during a pandemic. The information technology sector, for example, is one of the key sectors with the internet of things, automation, and offline changes to online, likewise with the health sector, both services, and sectors related to the procurement of medical supplies, which are an essential primary need in a pandemic situation.

When viewed from the gender aspect, several sectors are also important to the women's economy and are sectors that have been seriously affected by the pandemic. An example is the accommodation sector food \& beverage,

\footnotetext{
${ }^{13}$ Word Economic Forum, "The Future of Jobs Report 2018," 2018, http://www3.weforum. org/docs/WEF_Future_of_Jobs_2018.pdf.

${ }^{14}$ M. Adi Rahman, “Studi COVID-19: Dampak COVID-19 terhadap Ketenagakerjaan,” Webinar SMERU Research Institute - Dampak COVID-19 terhadap Ketenagakerjaan: Merancang Strategi Pemulihan Perekonomian Indonesia, June 10, 2020, https://smeru.or.id/id/content/dampak-covid19-terhadap-ketenagakerjaan-merancang-strategi-pemulihan-perekonomian-indonesia.
} 
where as much as $58.2 \%$ of the workforce are women. Likewise, other service sectors, where as much as $53.6 \%$ of the crew are women, and the absorption of female labor is quite high in the trade sector at $49 \%{ }^{15}$ Economic disruption in these sectors will have significant implications for gender profiles and relations related to the economy. On the other hand, the increasing number of sectors that have actually 'benefited' from the pandemic, is also important to read from a gender perspective: who benefits from the gender aspect of this situation, and whether there are other new risks with this situation as well. An example is the health sector: on the one hand, it shows that quite some women (who dominate this sector) can still get job opportunities, but on the other hand, there is also the issue of the exposure of health workers who are majority women to the risk of vovid-19 transmission. These questions are part of an important agenda to be answered from gender studies in seeing the impact of the COVID-19 pandemic.

In particular, this study finds that the economic impact is seen in at least 4 aspects: (1) Workspace and opportunities. Restrictions on mobility, the closure of tourist attractions, and the implementation of schooling from home have hit the economic sector hard. Some sectors are paralyzed and have implications for the loss of jobs or income. This can be seen in the tourism sector and its supporting sectors such as transportation services, hotels, food and souvenirs. Disruption to work and income is experienced by both men and women, because the various sectors affected have also become the mainstay of life for women and men. The processed food sector in tourist attractions, mostly managed by women, has experienced a decline in turnover of up to $80 \%$, even after making their marketing transformation offline to online. Meanwhile, the transportation sector, which men dominate, impacts the number of men who lose their jobs. (2) Ability to survive and unused skills. Limited mobility and community activities also result in jobs requiring skills that are not absorbed by the market. The disruption to market absorption of specific skills will be different due to the distribution of roles and the existing gender-based division of labor. Socially and culturally, some skills are attached as a feminine role. Therefore, many are mastered by women such as salon employees; or vice versa, skills associated with masculine performances and, therefore, are

\footnotetext{
${ }^{15}$ D'code Economic \& Financial Consulting, "Decoding the Economics of Covid-19," dcodeefc.com, 2020.
} 
dominated by men such as drivers, drivers, or pedicab drivers. Tour guides, drivers, rickshaw drivers lose their income because people reduce mobility. Barbers, salon workers, masseurs lose much of their income as people try to reduce exposure by keeping their distance. (3) Implication on productivity. Domestic work is often not considered productive work, because it has no economic value. In the context of a pandemic, women's workload for nurture and care has increased, so that women are considered increasingly unproductive. Domestic activities, caring for family members, including those who are sick, and ensuring the entire family's mental health actually have a very high economic value because they become the foundation for saving lives in a pandemic situation. However, the social construction of the meaning of productive work which is identical to that of the public, men, and the regular wage system makes it increasingly difficult for women in the informal sector to continue earning income. (4) Problems with access to social protection programs during a pandemic. Social protection becomes an important buffer when a crisis occurs, and the state is one of the keys to this buffer system. However, the informal sector, which women dominate, has several obstacles in accessing social protection programs because of the informality itself. Formal requirements, such as business permits \& collateral, cannot be fulfilled by the informal sector. Informality also makes them inadequate access to information and socio-economic security mechanisms because the distribution of these schemes usually uses formal channels. On the other hand, the schemes and channels for complaints when they cannot access the various existing socioeconomic guarantees are also very limited.

As explained above, the impact of a pandemic is no single. In other words, a pandemic will not only have a serious impact on the economic sector but also on the social side. It is clear that the pandemic, socially, has drastically influenced life patterns, especially because effective measures must be done by limiting the various activities of human interaction. This automatically "forces" the community to change the design of daily activities, which initially balanced between inside and outside the home, to almost entirely move home. The house becomes the main room for carrying out activities, whether considered productive or non-productive so that the dividing line between the two activities becomes blurred and mixed up. For women, this change has different implications because of their roles, which have been their responsibility in their daily lives. 
For women, studies that have been conducted, the implications of changing activity patterns due to pandemics, for example, are related to double burdens. The double burden issue existed long before the pandemic, but the pandemic has forced women to allocate more time and energy for nurture and care work because all family members are at home. There is no ideal role distribution even though each family member does their activities at home. Women still assume $80 \%$ of care and nurturing roles. It also has implications for the productive work of women who inevitably compete for time with nurture and care work. It is not the case for men who are not socially required to perform both roles. In different parts, the pandemic also contributes to the limited mobility of women because time and energy are drained in the house. This study shows an experience where even though the pandemic, men tend to be free to leave the house, one of which is doing activities at the covid-19 security posts in villages in Yogyakarta, which mainly implement local lockdown.

For women, a pandemic also increases the risk of domestic violence because the house is often the main locus of violence against women. KPPA (in Amidoni, 2020) notes that on March 2nd - April 25th, 2020, when social restrictions were carried out, there were 275 cases of violence experienced by adult women with a total of 277 victims. Another implication of the pandemic for women is the limited space and access to technology because so far, data shows that women's access to technology is still lagging behind. In fact, during a pandemic, almost all activities have shifted from offline to online. In this study, it was found that many women voiced about access to digital technology which was still expensive, which for women had implications for family spending priorities and allocations. The implication of the pandemic that women also feel is the cessation of communal spaces and schemes that have been spaces for interaction and encounter for women. The cessation of social activities such as social gathering, Family Welfare Development, and Integrated Service Post activities has a negative impact on women. So far, these activities have become a space for women to share their life burdens, access information, and act in solidarity. These communal spaces are also a forum for the actualization of women's leadership because so far women have been the backbone of these social schemes.

In addition, the impact of the COVID-19 pandemic is also related to how the power of technology is increasingly dominating. The change from offline to 
online is not just a technical matter. However, it also affects how productive activities experience a shift which is also a new challenge for informal sector workers. Likewise, daily routines suddenly give rise to new needs, namely access and skills to technology, especially the internet. It can be exemplified by the phenomenon of working and studying from home.

At first glance, the conditions that "force" humans to be more familiar with technology-based life appear to be a change that is not easy for all men, women, old and young. However, from a gender perspective, there is a narrative that cannot be generalized. Women who work in the informal sector and wives and mothers have a unique and more complex experience. Before the COVID-19 pandemic, women and technology were crucial issues. Women's access and skills in accessing technology are classified as low due to cultural problems, discriminatory work sector schemes and policies that do not have a gender perspective. This study shows how women are "forced" to adapt to technology during a pandemic but in overlapping roles, especially as workers and mothers. On the one hand, there is a need to transform his work online wherever possible, for example, selling online. On the other hand, there is also a demand for him to assist children who go to school online.

Analysis of the impact of this pandemic is relatively similar to discussing the impact of disasters from a gender perspective. The women's group is still more vulnerable so they experience more complex risks than men. However, the new issue here is the different characteristics of a pandemic disaster: it is more difficult to control, erratic, and unpredictable. In this context, daily narratives are essential to identifying the extent of the gender problem in the COVID-19 pandemic disaster itself.

\section{Typical Female Narrative about the COVID-19 Pandemic: Fear and Caution}

The investigation of women's daily experiences that we carried out resulted in sufficient space for female informants to narrate the meaning and meaning of the COVID-19 pandemic. At the beginning of the pandemic, this condition may be complicated to obtain due to limited information and space. The imposition of social restrictions and PSBB (Large-Scale Social Restrictions) is sufficient to limit direct interactions. The communities that women rely on in caring for their collective relationships are no longer accessible. Meanwhile, women have unique unrest in understanding the impact of the pandemic and 
reconciling their roles as humans, wives, mothers and workers who must be carried out in the same place, namely home.

As in the previous sub-chapters, the impacts felt by this pandemic are considered to be very different from the impacts of disasters that are usually experienced. In some ways, both women and men think that COVID-19 is a new type of disaster. It is because a pandemic is not a type of disaster that brings immediate damage like an earthquake, so it can be felt immediately and seen with the naked eye. The impact of a pandemic is felt in an indirect and prolonged manner.

Even though the felt impacts tend to be similar, there is a unique profound meaning for women about the COVID-19 pandemic. Women tend to interpret the pandemic in a spiritual context as a trial from God. In this context, informant said that spirituality was meant to refer to Islamic values. This meaning makes women more likely to accept the perceived conditions and risks during a pandemic. The attitude of acceptance that this woman chooses is not limited to a spiritual framework and manifests as an effort to overcome fears that are difficult to control. This fear may be interpreted as a manifestation of the feminine character that is often associated with women. The discourse that women are emotional creatures sometimes leads to the conclusion that women are weak subjects and need to be protected through more rational masculine control.

However, women who participated in this study said that this fear is indeed difficult to understand because the character of COVID-19 itself is not easy to predict. Various state policies have not succeeded in controlling the effects of the increasingly widespread pandemic. Meanwhile, at the family level, men who have been considered as the head of the household are even threatened with losing their jobs. In this situation, the women even think that they have to help their husbands to not get carried away with excessive psychological burdens. So, awareness of this fear leads women to spiritual attitudes to unravel stress and loosen psychological stress due to the pandemic. There are efforts to maintain mental health from an acceptance of pandemic conditions that are believed to keep the body in good shape and not be susceptible to being exposed to COVID-19.

However, women who participated in this study said that this fear is indeed difficult to understand because the character of COVID-19 itself is not 
easy to predict. Various state policies have not succeeded in controlling the effects of the increasingly widespread pandemic. Meanwhile, at the family level, men who have been considered as the head of the household are even threatened with losing their jobs. In this situation, the women even think that they have to help their husbands to not get carried away with excessive psychological burdens. So, awareness of this fear leads women to spiritual attitudes to unravel stress and loosen psychological stress due to the pandemic. There are efforts to maintain mental health from an acceptance of pandemic conditions that are believed to keep the body in good shape and not be susceptible to being exposed to COVID-19.

In certain conditions, gender roles and construction make women and men face different challenges and patterns of physical mobility. Priorities related to fulfilling gender roles, especially concerning nurture and care during an escalating pandemic, mean that women stay at home more than men. On the one hand, this results in lower exposure of women than men because it reduces the risk of transmission when meeting and interacting with other people. However, on the other hand, limited physical mobility is a challenge for women. The pandemic makes these meeting spaces limited, because gadget-based interactions cannot always replace the crucial role of social meeting spaces for women, such as social gatherings, Dasawisma meetings or religious gathering.

Another issue is related to anxiety and its implications for women's mental health. The insistent flow of information filled various social media channels to chat rooms in family, and closest neighbors responded by women with various attitudes. Some said that getting information was necessary. However, more informants complained that the flow of information was not all reliable and actually increased anxiety. Instead of filtering information, some women even took steps to minimize or cut off access to public information sources, such as television, to reduce their intake of information, which increases the level of anxiety. Women also worry about bored children because they cannot freely leave the house and cannot freely play with their peers, just as women also worry about how to convince older people who have difficulty understanding or adapting to new situations due to the pandemic. Anxiety in facing a pandemic also illustrates the relationship between the chaotic flow of information and the waning level of confidence in how the pandemic crisis situation will be managed. Distrust of the role and capacity of authorities such as the state and other social institutions in managing the pandemic crisis is also seen in the apathy of women regarding pandemic management policies. 
As described above, the specific conditions of women show that it is not only consideration of personal safety that is an important concern for women. But furthermore, considerations of both women's caution and anxiety are part of her efforts to fulfill her gender roles. Women become careful because there are social responsibilities or habits related to looking after children and family members. Habits as caregivers and anxiety and fear due to awareness of vulnerability are powerful narratives in women's daily lives during a pandemic. This narrative that is unique to women then raises the question: do women have specific vulnerabilities or do women also have better potential and wisdom in interpreting and managing crises?

\section{The Daily Activities Cycle of Women during a Pandemic: Change, Vulnerability and Resilience}

A daily activities cycle is a simple tool that can open up an analysis related to the division of labor. When juxtaposed between men's and women's daily activities cycles, this tool can also track whether there is a difference in the variety of activities and time frame between the two and what does that means? Further tracking makes it possible to look at the driving factors that make a gender-based division of labor possible.

In previous research, by illustrating the daily lives of fisherwomen in Tambaklorok, Fatimah et al. showed that women's work tends to be more complex because of their roles as mothers, wives, and informal sector workers at the same time. For women, work does not necessarily mean a money-making activity like what men do, which is closely related to the role of breadwinner. However, women's work includes activities when helping her husband to earn a living, taking care of housework, worshiping, and other social activities. The working hours required are also relatively longer because women start their activities earlier before all family members wake up in the morning (Figure 1). ${ }^{16}$

The daily activities cycle shows that women's work seems invisible, seems trivial, and only a few are of economic value but are routine with an endless amount. Many women then become time-poor because they hardly have time to socialize and even rest for themselves. Meanwhile, men's jobs are few but of

\footnotetext{
${ }^{16}$ Dati Fatimah et al, Ketangguhan yang Tersembunyi: Narasi Perempuan pada Strategi Bertahan dari Dampak Perubahan Iklim (Studi Kasus Tiga Daerah: Gunungkidul, Semarang dan Ogan Komering Ilir) (Jakarta: Friedrich-Ebert-Stiftung Indonesia, 2018).
} 
long duration and have high economic value. In addition, men also have more free time to rest and interact socially outside of working hours. These differences in activities can be interpreted as a result of discriminatory gender constructions and impact a double burden for women. The standardization of gender roles has normalized the contribution of women in the domestic sphere as an obligation, habit, and culture. Meanwhile, while women also work in the public sector to meet their family's economic needs, they are only considered a complement.

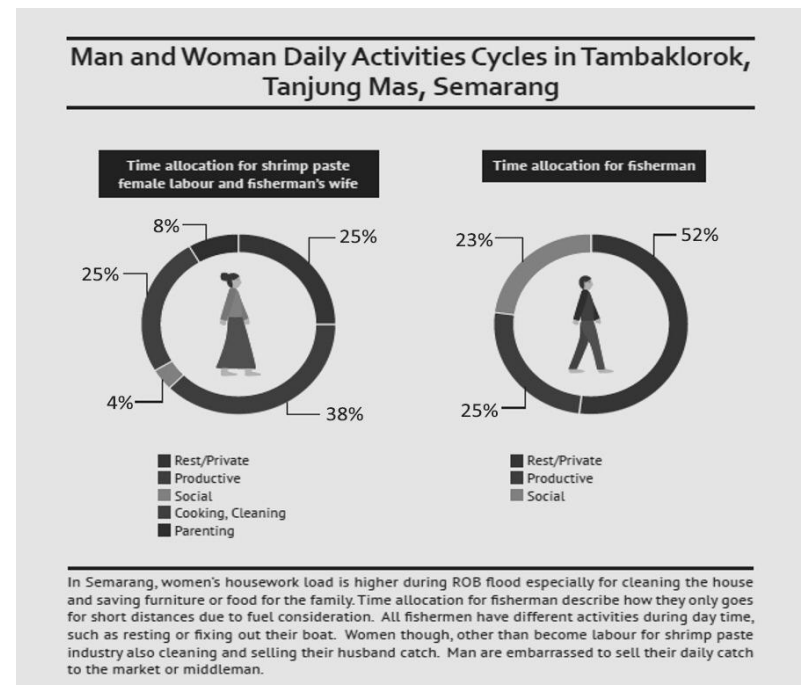

Figure 1.

Men and Women Daily Cycles in Kampung Tambaklorok, Tanjung Mas, Semarang ${ }^{17}$

During the pandemic, tracing the daily activities cycle of women was not only limited to differences in work activities influenced by gender construction. However, women's daily experiences during the pandemic provide more diverse meanings, especially regarding the importance of alternative scenarios in understanding the public and private dichotomy. This can be seen from this study which is illustrated in the diagram (Figure 2) about the daily lives of women informal sector workers during the COVID-19 pandemic.

${ }^{17}$ Fatimah et al. 


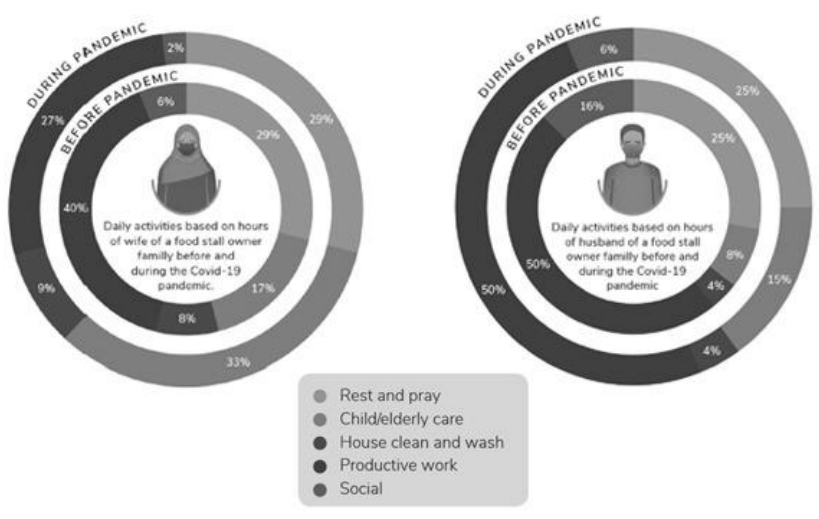

Figure 2

The Daily Cycle of Women and Men in the Informal Sector before and after the COVID-19 pandemic

The diagram illustrates the daily life of Nur (not her real name), a woman who works as a vegetable trader at her house. Nur's daily activities cycle is depicted on the left, while on the right, is the daily activities cycle of Wahyu (also not his real name), Nur's husband who works as a travel driver.

Nur has been selling vegetables for a long time at the shop in front of her house. Nur cooks and peddles cooked food, rice and side dishes such as traditional Javanese salad with peanut sauce (pecel), vegetable stew in coconut milk (sayur lodeh), soup, sautéed papaya leaves (oseng daun papaya), spicy fried fish (ikan balado) and hot fried foods. Her customers are neighbors in her village, boarding house boys and construction workers. In addition, Nur is also a mother of 3 children, including one of them who is 1.5 years old and a nephew of a divorce victim who is currently in grade $1 \mathrm{SD}$. Apart from the nuclear family, Nur still has to share her attention with her elderly parents who live not far from the house where she lives.

Like women who are informal entrepreneurs, Nur's daily life before the pandemic has been filled with very dense activities. Starting from leaving for daily/wholesale shopping to the market, arranging groceries and stalls, preparing breakfast and school children, taking care of their parents, cleaning the house, including washing clothes and dishes. However, the busy daily 
agenda has multiplied during the pandemic. The activities of nurture and care have almost doubled, from the previous one or from $17 \%$ to $33 \%$. These activities for caring for children and the elderly are related to accompanying children and nephews who are studying at home. For Nur, accompanying children learning online is quite difficult, because apart from understanding the substance of the teaching, they also have to adapt to the child's psychological condition and the online education model. Many women have complained about the online education model, because they have to be extra in accompanying children in learning. In addition, women like Nur have to devote more time to taking care of their fathers, who have to go to a hospital for health checks where there are different arrangements during a pandemic.

Because the time for nurture and care is doubled, the implication is that there is less time for women to do productive activities and social activities. There is a clear difference in the time frame situation before and after the pandemic for productive activities. The time spent on women for productive work has decreased significantly, from previously $40 \%$ to $27 \%$, and social activities, from the previous $5 \%$ to $2 \%$.

In practice, women like Nur also often do more than one job at the same time, such as selling while accompanying children to study at home; or cooking while sweeping or washing dishes. At certain times such as the morning will be a very busy time for women to prepare various things and this condition becomes even more pronounced during a pandemic situation. This role, which is often referred to as multi-tasking, is a socially acceptable choice. The morning time when it comes to preparing breakfast is an important time when children go to school. Or during a pandemic, busy shop hours, for example, serve customers who will buy raw vegetables and online lessons for children in the morning. It puts women in a challenging situation because they have to divide their limited time, energy, and attention for various activities simultaneously. The issue of double burdens becomes an increasingly crucial issue in a pandemic situation, especially when productive work and domestic work are mixed in a locus called home. In other words, the gender-based division of labor tends to concentrate care work on women. Daily cycles and time frames also show how gender-based division of labor becomes a practice that occurs and is cared for in family and social institutions. From this daily activities cycle, we 
read what is considered socially as women's work, and what is socially associated with men's work.

However, the gender construction that places men as the head of the household, with responsibility as breadwinners, is correlated with the bulk of his daily time spent in productive work. In the illustration of the daily activities cycle above, a man who works in the transportation service sector has a wife as a food seller. In the period before the pandemic, in 24 hours, half of men's time was allocated to productive work, followed by rest and worship and social activities. Work as a caregiver and domestic only about $12 \%$ of the total daily time. This gender role is in line with a common construction, where men are positioned as breadwinners. During the pandemic, the role of men as breadwinners has remained relatively unchanged, but the time spent for care has a significant increase in proportion to the decrease in social activity. As the main breadwinner, the income of men, especially those who work in the transportation-tourism sector, like Nur's husband, decreased significantly. This situation raises anxiety, stress because the gender role as wage earner cannot be fulfilled.

In the early days of the pandemic, Nur's husband still hoped to get a "work share" from the travel he worked for, which then put his hopes in the work of transporting goods. However, the situation is not always possible for Nur's husband to get orders even once per week. In addition to staying afloat by relying on her main job in transportation services, she tries to keep working according to her skills. However, this also does not provide sufficient income. The situation, which seemed no longer ideal, prompted both of them to rethink their respective functions and roles so far. In practice, they agreed that Nur's productive work was partially taken over by her husband even though there were jobs that could not be fully handed over, such as "processing food". Nur's husband also took a more role in parenting, especially caring for the youngest child when Nur had to accompany the child and her niece to study. Here, they seem to realize that the gender roles they have implemented so far are not flexible enough to handle crises.

Based on the experience of women like Nur, it is actually seen that women always work in their capacity as mothers and wives whose goals are the same, namely for the welfare of the family. There is no different motive between when 
women do domestic work and become wage labor other than for the welfare of family members including themselves. The problem is that women are often considered a domestic symbol and the meaning of home is only reduced to a place to live and an area of consumption. The symbol of economic rationalism and productivity is public activity. So as previously explained, whatever is done by women will always be seen as "mothering" activities that do not have high economic value. So that economic activity is limited to the low-wage informal sector. But basically, the public-private separation does not come from women's experiences and wisdom.

Once again, the dynamics of the daily activities cycle of women such as Nur shows how the public and private dichotomy is not very useful in overcoming the impact of this epidemic, both socially and economically. The strategy carried out actually shows that public and private functions must be viewed equally so that the sustainability of economic productivity at the family level can be well managed. Economic defense in the public sphere is also not meaningful without being balanced with domestic activities. This perspective on equality is also aimed at avoiding conflicts within the household and exacerbating risks. Meanwhile, in a crisis situation, efforts to protect each other between family members are the minimum defense in overcoming the COVID-19 outbreak. Women like Nur realize that their husband's income is no longer promising. However, they do not question the "failure" because in the end they believe that every role they play has the same goal and contribution to the welfare of their family.

\section{Conclusion}

The impact of the COVID-19 pandemic is felt in all aspects of human life, especially because a pandemic is a type of disaster different from other common disasters that often occur in Indonesia. The most felt impact of a pandemic is a drastic change in patterns of daily activities. The social mobility of the community is limited because most activities must be carried out from within the home, including school activities and productive work, where the majority of which move to use online technology. Restrictions on activities outside the home also have implications for the slowing down of the economy in various work sectors. However, workers in the informal sector are most affected because they depend on their income/wages on daily economic 
activities or transactions. With the drastic reduction in community activity in public space, the economy of this group has also stalled.

For women, the impact of the COVID-19 pandemic is not only a health or economic issue but also a complex shift in daily activities cycles. Some call it the double burdens. The problem of double burdens does not only arise during the pandemic, but the pandemic makes the nurture and care work longer and take up more time and energy. The movement of most public activities into the home makes the boundaries between productive and non-productive work blurred and mixed up. Office work can be done simultaneously with accompanying children to study. The blurred boundaries between productive and non-productive work have different effects on men and women because of the gender roles. Socially, the piece is attached and socialized as women's responsibility, so the implication of a pandemic on a double burden is a problem many women face. Social changes occur because of the pandemic, but they do not automatically change the existing norms and practices for genderbased division of labor. For women, this change in activity patterns automatically brings various implications, especially an increase in the workload of women who struggle between productive and domestic work and the role of caring in line with the implementation of school and work from home.

However, this double burden is the implication of building an economic structure based on the separation of public and private spaces. So, under certain conditions, double burden can also be interpreted as a woman's rational choice because she also has an interest in maintaining family welfare whether economically, socially, psychologically, and physically. But what about the welfare of women themselves? Meanwhile, during the COVID-19 pandemic, economic policies were still very conventional and were not even sufficiently resilient to prolonged crises. Economic activities are only translated as activities of male breadwinners and within the boundaries of public spaces or outside the home. It makes women appear economically unproductive. Although the COVID-19 pandemic demonstrates how much human dependence and economic linkage is to domestic activities as a strategy to survive the prolonged crisis, it is important not only to conclude that the daily activities cycle of women during the COVID-19 pandemic is limited to discussions about the 
emergence of a double burden. However, these women's daily experiences need to be used as a reference in creating alternative scenarios. The work of women that has been concentrated on care work can be recognized in economic policy.

In fact, many feminist economic approaches have previously discussed the urgency of alternative policies such as the care economy. Vaughan, ${ }^{18}$ for example, offers the concept of "gift economy" to deconstruct mothering activities which tend to be denigrated in a misogynistic view. Meanwhile, Elson ${ }^{19}$ more practically offers the idea of triple $\mathrm{R}$, namely recognize, reduce, and redistribute unpaid care work as an effort to eliminate gender gaps in the global economic structure. Regarding the care economy, Esquivel ${ }^{20}$ also emphasizes the importance of state involvement in overcoming cultural problems. The term care in a feminist perspective oriented towards equality does not always clash with the concept of patriarchal bias. Therefore, alternative policies to recognize women's work also need to be synchronized with the context of society to map the roots of dominating power relations. However, in principle, the alternative approach must be based on reducing inequality, redistributing wealth, and fulfilling human rights. In the context of a pandemic, policies to recognize and strengthen women's capacities must be integrated with crisis management. The crisis during the COVID-19 pandemic can also be a momentum to build social protection policies that place women's experience and knowledge as the main input.

\section{Funding}

This research was conducted in collaboration with the SRI Institute which is funded by Friedrich-Ebert-Stiftung (FES) Jakarta. The research was conducted in May-June 2020.[s]

\footnotetext{
${ }^{18}$ Vaughan Genevieve, "36 Steps Toward a Gift Economy," gift-economy.com, 2002, http://www.gift-economy.com/articlesAndEssays/36steps.html.

${ }^{19}$ Diane Elson, "Recognize, Reduce, and Redistribute Unpaid Care Work: How to Close the Gender Gap," New Labor Forum 26, no. 2 (2017): 52-61, https://doi.org/10.1177/ 1095796017700135.

${ }^{20}$ Valeria Esquivel, "What Is a Transformative Approach to Care, and Why Do We Need It?," Gender \& Development 22, no. 3 (2014): 423-39, https://doi.org/10.1080/13552074.2014.963303.
} 
The Changes in the Daily Activities Cycle of Women Informal Workers ....

\section{References}

Ayesha, Ahmad. "Conceptualizing Disasters from a Gender Perspective." In Disasters: Core Concepts and Ethical Theories, edited by Dónal P. O”Mathúna, Vilius Dranseika, and Bert Gordijn, 105-18. Switzerland: Springer International Publishing, 2018.

Biro Pusat Statistik “Perilaku Masyarakat di Masa Pandemi COVID-19.” bps.go.id, 2020. https://www.bps.go.id/publication/2020/09/28/f376dc33cfcdeec4a514f09c/p erilaku-masyarakat-di-masa-pandemi-covid-19.html.

D'code Economic \& Financial Consulting. "Decoding the Economics of Covid-19." dcodeefc.com, 2020.

Djalante, Riyanti, Jonatan Lassa, Davin Setiamarga, Aruminingsih Sudjatma, Mochamad Indrawan, Budi Haryanto, Choirul Mahfud, et al. "Review and Analysis of Current Responses to COVID-19 in Indonesia: Period of January to March 2020." Progress in Disaster Science 6 (2020): 100091. https://doi.org/ 10.1016/j.pdisas.2020.100091.

Elson, Diane. "Recognize, Reduce, and Redistribute Unpaid Care Work: How to Close the Gender Gap." New Labor Forum 26, no. 2 (2017): 52-61. https://doi.org/ $10.1177 / 1095796017700135$.

Esquivel, Valeria. "What Is a Transformative Approach to Care, and Why Do We Need It?" Gender \& Development 22, no. 3 (2014): 423-39. https://doi.org/10.1080/ 13552074.2014.963303.

Fatimah, Dati, Aminatun Zubaedah, Henri Ramdlaningrum, Ahmad Sarkawi, Dian Ajeng Pangestu, and Mida Mardhiyyah. Ketangguhan yang Tersembunyi: Narasi Perempuan pada Strategi Bertahan dari Dampak Perubahan Iklim (Studi Kasus Tiga Daerah: Gunungkidul, Semarang dan Ogan Komering Ilir). Jakarta: FriedrichEbert-Stiftung Indonesia, 2018.

Freedman, Jane. Concepts in the Social Sciences Feminism. Buckingham: Open University Press, 2003.

Genevieve, Vaughan. "36 Steps Toward a Gift Economy." gift-economy.com, 2002. http://www.gift-economy.com/articlesAndEssays/36steps.html.

Gunnarsson, Lena. "A Defence of the Category 'Women."' Feminist Theory 12, no. 1 (2011): 23-37. https://doi.org/10.1177/1464700110390604.

Komisi Nasional Anti Kekerasan terhadap Perempuan. "Pernyataan Sikap Komnas Perempuan: Urgensi Perspektif HAM dengan Perhatian Khusus pada Kerentanan Perempuan dalam Penanganan Pandemi COVID-19." komnasperempuan. go.id, 2020. https://komnasperempuan.go.id/pernyataan-sikap-detail/ pernyataan-sikap-komnas-perempuan-urgensi-perspektif-ham-denganperhatian-khusus-pada-kerentanan-perempuan-dalam-penanganan-pandemicovid-19. 
MacKinnon, Jessica, and Alexane Bremshey. "Perspectives from a Webinar: COVID-19 and Sexual and Reproductive Health and Rights." Sexual and Reproductive Health Matters 28, no. 1 (2020): 1763578. https://doi.org/10.1080/26410397.2020. 1763578.

Mahmood, Saba. "Feminist Theory, Embodiment, and the Docile Agent: Some Reflections on the Egyptian Islamic Revival." Cultural Anthropology 16, no. 2 (2001): 202-36. https://doi.org/10.1525/can.2001.16.2.202.

Mies, Maria. "Toward a Methodology for Feminist Research." In Theories of Women's Studies, edited by Gloria Bowles and Renate Klein, 117-39. London: Routledge, 1983.

Rahman, M. Adi. "Studi COVID-19: Dampak COVID-19 terhadap Ketenagakerjaan." Webinar SMERU Research Institute - Dampak COVID-19 terhadap Ketenagakerjaan: Merancang Strategi Pemulihan Perekonomian Indonesia, June 10, 2020. https://smeru.or.id/id/content/dampak-covid-19-terhadap-ketenagakerjaanmerancang-strategi-pemulihan-perekonomian-indonesia.

Rayaprol, Aparna. "Feminist Research: Redefining Methodology in the Social Sciences." Contributions to Indian Sociology 50, no. 3 (2016): 368-88. https://doi.org/ 10.1177/0069966716657460.

UN Woman - Asia Pasific. "Indonesia and COVID-19: Impact on the Private Sector." asiapacific.unwomen.org, 2020. https://asiapacific.unwomen.org/en/digitallibrary/publications/2020/08/indonesia-and-covid-19-impact-on-the-privatesector.

Winanti, Poppy S., and Wawan Mas'udi. Tata Kelola Penanganan COVID-19 di Indonesia: Kajian Awal. Yogyakarta: Gajah Mada University Press, 2020.

Word Economic Forum. "The Future of Jobs Report 2018," 2018. http://www3. weforum.org/docs/WEF_Future_of_Jobs_2018.pdf. 